\title{
Quality and Price Variation in the Dairy Value Chian: A Case Study in Monaragala District, Sri Lanka
}

\author{
P. S. S. L. Wickrama ${ }^{1}$, A.L. Sandika ${ }^{2 *}$, V.S. Jayamanne ${ }^{3}$
}

1,2 Department of Agricultural Economics, Faculty of Agriculture, University of Ruhuna, Mapalana, Kamburupitiya, Sri Lanka.

${ }^{3}$ Department of Food Science and Technology, Faculty of Agriculture, University of Ruhuna, Mapalana, Kamburupitiya, Sri Lanka

\section{Correspondence:}

${ }^{1}$ sandika@agecon.ruh.ac.lk,

(iD) https://orcid.org/0000-0002-1136-5537

DOI: http://doi.org/10.4038/sljae.v2i2.43

\begin{abstract}
Low value addition, quality and price variations have been recognized as common problems of value chains in developing countries. Objective of the present study was to examine the quality and price variations throughout the dairy value chain in a less developed region in Sri Lanka. Wellawaya divisional secretariat of Monaragala district was purposively selected as the study area. Primary data were collected by using pre-tested, structured questionnaires. Laboratory tests of milk and curd samples were carried out to check the quality variation using standard methods. Milk samples were collected from three levels including farmer (10), processor (10 from each, milk and curd) and retailer (10) to determine the quality variation. According to the results, price of curd and yoghurt at consumer level was increased by $36 \%$ and $77 \%$ compared to the farm gate price. Farmer received the highest profit per liter of milk (68.00 LKR) in the shortest value chain (D) out of four main chains identified. The markets' margin was estimated at 36\%. Farmer had the largest share of $64 \%$ followed by processor (20\%), retailer (8\%), collector (4\%), and wholesaler (4\%). It was evident that farmers received fair profit through all four dairy value chains. However, solid non-fat percentage, specific gravity and $\mathrm{pH}$ of analyzed samples through the value chain were not comply with the standards. In conclusion, the prices of dairy products have increased while deteriorating the quality along the chain. It is therefore important to educate and train actors throughout the dairy value chain on quality management.
\end{abstract}

Keywords: Dairy farmers, dairy value chain actors, price variation, quality variation 


\section{Introduction}

Value chain defines as a set of activities that a firm operating in a specific industry performs to deliver valuable products (Porter 1985). According to the Kaplinsky and Morris (2001) the value chain is the full range of activities which are required to bring a product or service from conception, through the different phases of production (involving a combination of physical transformation and the input of various producer services), delivery to final consumers, and final disposal after use. In dairy industry, different value chain actors can be identified such as input suppliers, milk producers, milk processors, marketers (wholesalers and retailers), and consumers. Further, it includes different value-added products such as curd, yoghurt, pasteurized milk, and ice cream. Dairy milk is an essential source of supplements to human and animals and it is the first and the main nourishment for the mammals (Walzeem et al. 2002). Dairy milk is therefore considered as a main food for the human. The utilization of dairy and dairy items is common in Sri Lanka which is perishable. Due to their perishable nature, there is a greater chance for quality deterioration from product conception to utilization ultimately affecting the buyer wellbeing. Enhancing product quality and safety through arrangement of good hygienic operations are desirable for customers. This is one of the motivations behind why dairy testing is important to control quality and hygienic. (Giangiacomo et al. 2000). Customers throughout the world are progressively worried about the safety of their nourishment in general and dairy and dairy items specifically. There is limited information on hygiene practices, quality and the price variations of the dairy value chain in Sri Lanka. Therefore, the development of infrastructure such as milk collecting networks, facilities for value addition, processing, and quality assurance remain as challenges for smooth growth of the industry.

Dairy industry plays a significant role in the Sri Lankan economy. Total annual milk production of the country is 447.5 million liters and there are 0.176 million dairy farmers involved in the industry (DCS 2016). Smallholders play the main role in the livestock industry including dairy. Altogether, 3.5 million people including farmers and other actors depend on the industry (FAO, 2009). The livestock sector contributed more than 
22.5 billion rupees to the GDP (FAO 2009). Currently livestock contributes to $1 \%$ to the GDP (DAPH 2019). Approximately 17.9 percent of family units own domesticated animals and around $70 \%$ of them own cattle in Sri Lanka. The dairy animal population comprises of 1.21 million cows in Sri Lanka (FAO 2009). In 2016, import of dairy and dairy products has been expanded by $15 \%$ compared to 2015 . As a result, annual per-capita accessibility of milk and allied products expanded by 55.5 liters (DAPH 2016; DCS 2016).

Less numbers of milk collection agencies, chilling centers and low chilling capacity have negatively affected the dairy value chain in Monaragala district (DAPH 2011). On the other hand, potential economic gains of actors have drained out due to low-quality value-added products, poor quality control practices, and lack of product differentiation in the value chain. Poor infrastructure facilities such as poor transport, training facilities, and farm infrastructure facilities also have contributed to the current position of the value chain. Poor knowledge about quality and safety of milk products also have caused considerable economical and health losses to consumers (Vernooij et al. 2015). Milk is highly perishable in nature and they should be brought to the consumer as quickly as possible in order to satisfy the market requirements. Even, the retailer also should sell the products as soon as possible to avoid qualitative and quantitative losses. Thus, proper management of value chain is important for nutritional preservation, food and financial security of the players and produce best value-added products. Therefore, the objectives of this study were to identify the value chain and assess market margin of dairy value chain, and quality and price variations.

\section{Materials and methods}

This study was conducted in Monaragala district. By considering the high number of dairy farmers scattered in the area. Wellawaya Divisional Secretariat (DS) division was purposively selected for this study among eleven DS divisions of Monaragala district. It is the highest populated DS division in Monaragala. This study followed value chain approach starting from farmer, collector, processor and marketer (wholesaler and retailer) to consumer in Wellawaya DS division. Representation of all the actors in the dairy value chain was considered. Farmers list of the Wellawaya veterinary office, Wellawaya DS division and Milco collecting center was used as a sampling 
frame to select forty dairy farmers from the target population. Stratified random sampling method was used to select 20 small scales, 10 medium scale, and 10 large scale farmers to represent different production scales. Apart from that, 10 input suppliers, 10 collectors, 10 processors, two wholesalers, 13 retailers, and 15 consumers were selected purposively.

Six different structured questionnaires were used for primary data collection from each dairy value chain actor. Questionnaires consisted three components such as basic socio demographic variables, prices and other economic variables, and maintenance of quality parameters. Secondary data were collected through literature such as books, journal articles, newspapers, and websites.

Milk samples were collected randomly from three main actor levels including ten milk samples each from farmer and processor level, and ten curd samples from wholesaler level. Laboratory tests were conducted to check the quality variation throughout the value chain.

Milk quality parameters were measured to identifying quality variation along the dairy value chain from farmer to wholesaler. Fat percentage, solid non-fat (SNF) percentage, specific gravity and pH were determined by using standard methods at three main actor levels of milk value chain. Laboratory tests were carried out at Milco milk collection center laboratory, Wellawaya and animal science and technology laboratory, Department of Animal Science, Faculty of Agriculture, University of Ruhuna. Fat percentage, SNF percentage and specific gravity were tested only at farmer and collector level. The $\mathrm{pH}$ was tested only at processor level on availability of facilities and time.

Fat percentages were determined by using standard Gerber method. Specific gravity was determined according to the standard lactometer reading method. The $\mathrm{pH}$ values were taken by using $\mathrm{pH}$ meter. The SNF percentages were identified by using Eq. 1 (Richmand's formula).

$S N F \%=(C L R / 4)+0.22 F+0.72$

Where;

SNF = solid non-fat percentage $(\%)$

$\mathrm{CLR}=$ corrected lactometer reading $\mathrm{F}=$ fat content in milk $(\%)$

Market Margin (MM) was used to study the price spread. It is the difference 
between the price paid by the ultimate consumer and the price received by the producer or farmer. The MM represents all assembling, transport, other retailing charges and profit margin added to the farm products i.e., the cost of providing a range of marketing services (Khan at el. 2005). Simply it can be identified as the percentage difference in price paid by the buyer and price received by the seller.

Market margin for curd $=(P s / S p) \times 100 \%$

Where;

Ps = price spread (paid price - sale price in rupees)...... (3)

$\mathrm{Sp}=$ sale price in rupees

Assuming,

Farm gate price $\quad=\mathrm{a}$

Collector price $\quad=\mathrm{b}$

Processor price $\quad=\mathrm{c}$

Wholesaler price $\quad=\mathrm{d}$

$$
\begin{array}{ll}
\text { Retailer price } & =\mathrm{e} \\
\text { Market margin } \% & =\{(\mathrm{e}-\mathrm{a}) / \mathrm{e}\} \times 100 \% \\
\text { Farmer's share } \% & =\{\mathrm{a} / \mathrm{e}\} \times 100 \% \\
\text { Collector's share } & =\{(\mathrm{b}-\mathrm{a}) / \mathrm{e}\} \times 100 \% \\
\text { Processor's share } & =\{(\mathrm{c}-\mathrm{b}) / \mathrm{e}\} \times 100 \% \\
\text { Wholesaler's share } & =\{(\mathrm{d}-\mathrm{c}) / \mathrm{e}\} \times 100 \% \\
\text { Retailer's share } & =\{(\mathrm{e}-\mathrm{d}) / \mathrm{e}\} \times 100 \%
\end{array}
$$

Procedure used to calculate costs and profits is indicated in Eq. 4

Average cost of production per liter of milk = (Average total cost per animal) (Average yield per animal)

\section{Results and discussion}

Input suppliers, farmers, dairy collectors, processors, marketers and consumers were the main actors who engaged in dairy value chain in Wellawaya DS division. Four types of dairy value chains were identified and shown in Fig.1. 


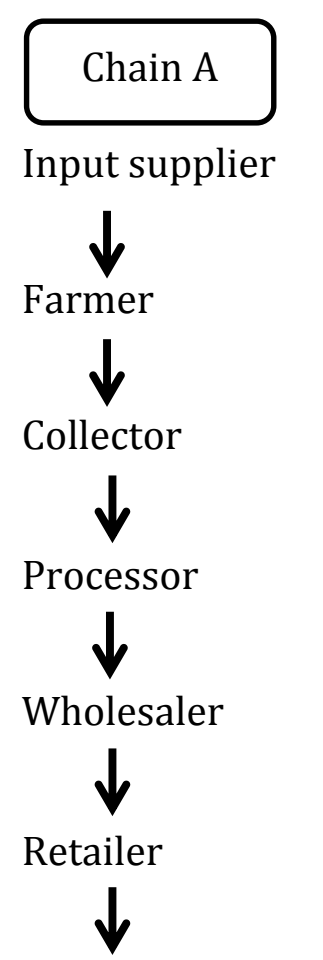

Consumer

Eg: curd, yoghurt
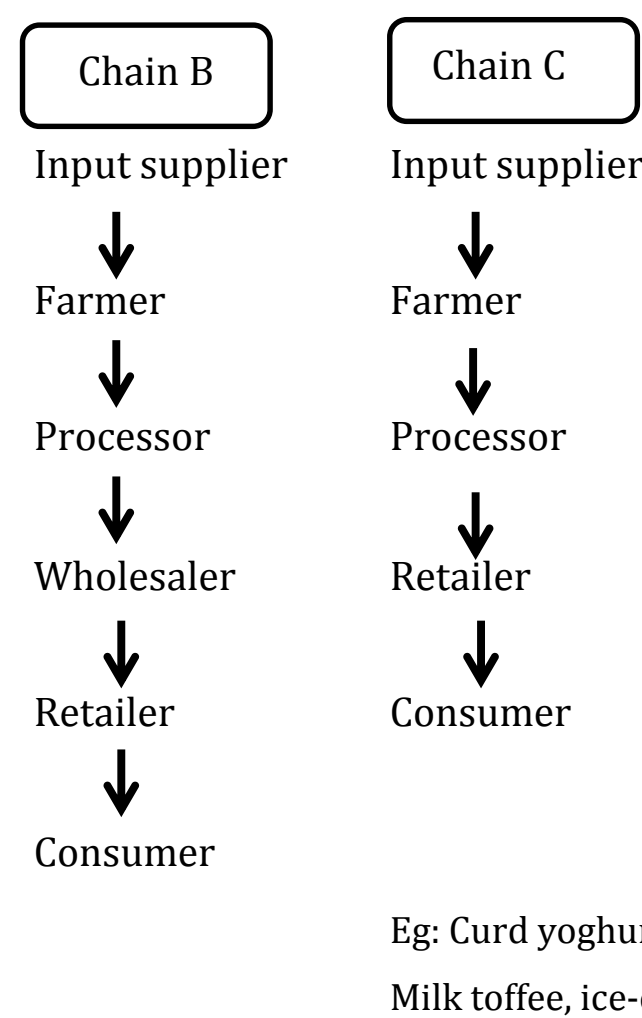

Input supplier
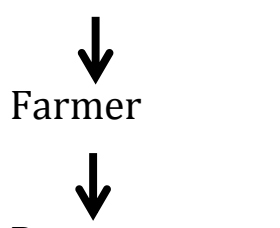

Processor
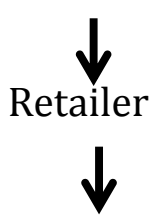

Consumer

Eg: Curd, yoghurt

Eg: Curd yoghurt
Chain D

Input supplier

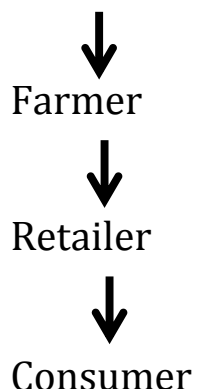

Eg: Fresh milk

Milk toffee, ice-cream

Figure 1: Different dairy value chains in the study area

Curd, yoghurt, milk toffee and ice cream were the main end products of the value chains. In the sample, majority of farmers $(35 \%)$ were linked to Chain $\mathrm{A}$, while $28 \%$ and $25 \%$ of farmers were linked to Chain B and C, respectively. The rest (12\%) was linked to Chain D.

Average profit calculation was made aggregating both buffalo and cow milk. This aggregation was made because, in general, both cow and buffalo milk is mixed together by collectors in all the identified value chains. Costs and profits for production of one liter of milk were calculated as below.
Average cost of production per liter of milk,

Average yield of milk per animal

$$
=3 \text { liters per day }
$$

Average cost per animal

$$
=\text { Rs. } 95 \text { per day }
$$

Average cost per liter of milk

$$
=\text { Rs.31.66 per day }
$$

Farmer's average profit, farm gate price and cost variations per liter of milk in the four main value chains are shown in Table 1. 
Table 1: Cost, price and profit variations at farmer level in each value chain

\begin{tabular}{lrrrr}
\hline Components & Chain A & Chain B & Chain C & Chain D \\
& & & & \\
\hline Average cost (LKR/Liter) & 32 & 32 & 32 & 32 \\
Average farm gate price (LKR/Liter) & 80 & 85 & 85 & 100 \\
Average profit (LKR/Liter) & 48 & 53 & 53 & 68 \\
\hline
\end{tabular}

Table 2: Curd and yoghurt average price variation at each actor level

\begin{tabular}{lllllc}
\hline Level & $\begin{array}{l}\text { Farmer } \\
\text { level }\end{array}$ & $\begin{array}{l}\text { Collector } \\
\text { level }\end{array}$ & $\begin{array}{l}\text { Processor } \\
\text { level }\end{array}$ & $\begin{array}{l}\text { Wholesaler Retailer } \\
\text { level }\end{array}$ & level \\
\hline $\begin{array}{l}\text { Curd price per } \\
\text { liter of raw milk equivalent }\end{array}$ & 80 & 85 & 110 & 115 & 125 \\
$\begin{array}{l}\text { Yoghurt price per liter raw } \\
\text { milk equivalent }\end{array}$ & 80 & 120 & 240 & 300 & 350 \\
\hline
\end{tabular}

As shown in Table 1, farm gate price of milk per liter varied across different value chains. The highest average farm gate price and profit were reported in value Chain D. Hence, supplying to chain $\mathrm{D}$ is the most profitable to the farmer. Value Chain A is the least profitable for the dairy farmers in Wellawaya area.

Table 2 shows the average price variation of curd and yoghurt at different value chain actor levels as the two main products. Curd and yoghurt were delivered via chain A, B and C.
By considering price variation through each level of the dairy value chain as in table 2, mean price of curd varied from 80.00 LKR to 125.00 LKR per liter in between farmer level to consumer level in all four value chains $(A, B, C, D)$. Mean price of yoghurt was varied in between Rs.80.00 to Rs.350.00 per liter.

The distribution of market margin and farmer share among the value chain actors in Chain A is shown in Figure 2. 


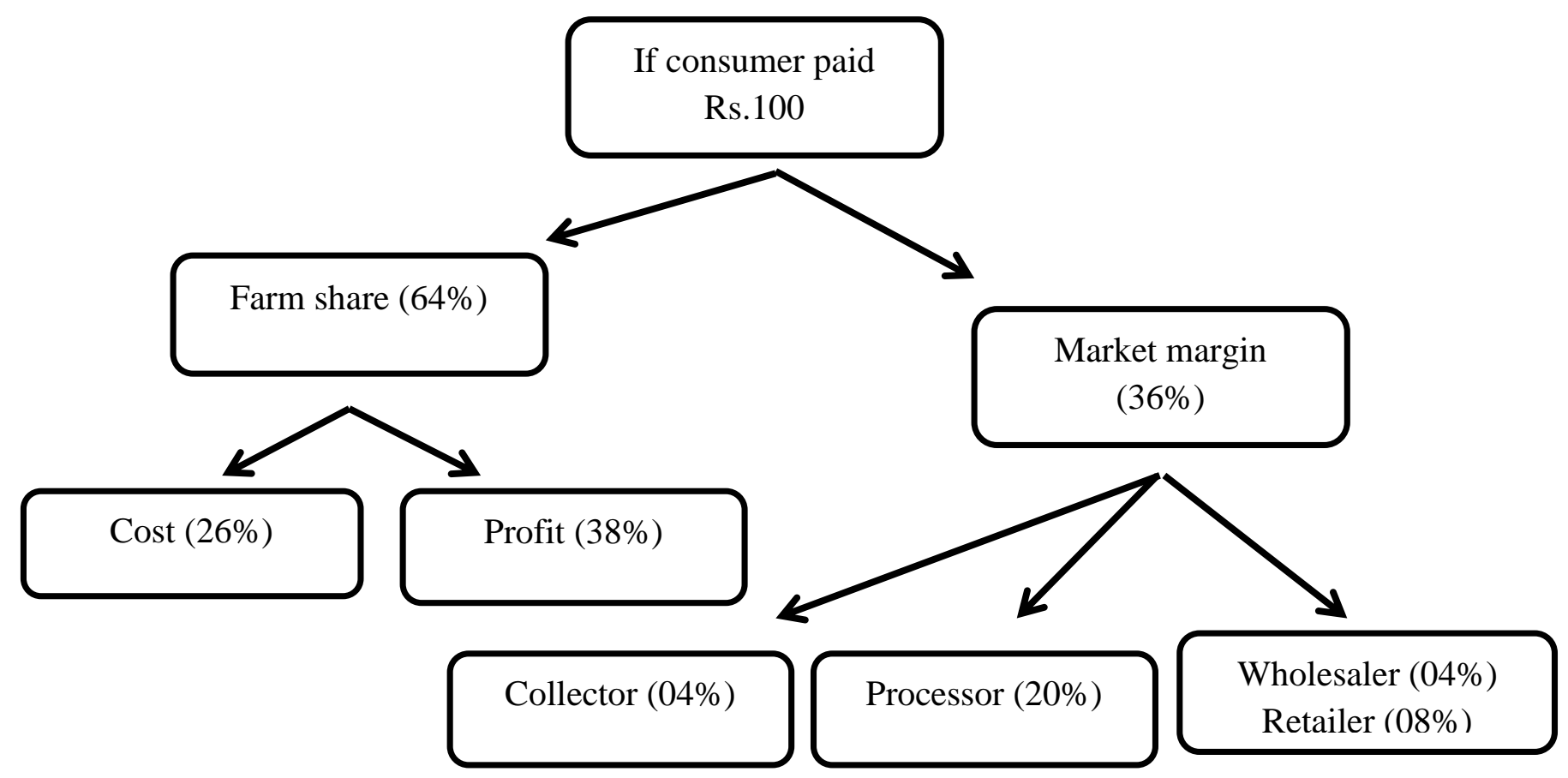

Figure 2: Market margin distribution in Chain A

When considering Fig. 2, if consumer pays a $100 \mathrm{LKR}$, farmer share is $64 \%$ in which, cost of production consists of $26 \%$ while $38 \%$ goes as the profit. Compared to the other actors, the second largest margin was accrued to the processor (20\%). Each wholesaler and collector received the least share accounted at $04 \%$.

Table 3 shows the fat $\%, \mathrm{SNF} \%$ and specific gravity variation of milk samples at farmer level. Considering the quality variation at farmer level, fat percentage of ten milk samples varied from $3.8 \%$ to $5.0 \%$ and mean fat percentage of milk samples was $4.34 \%$. The SNF percentage of ten milk samples varied between $8.34 \%$ to $9.1 \%$ while mean SNF percentage was $8.69 \%$. Also, specific gravity varied between 1.028 to 1.030 $\mathrm{g} / \mathrm{ml}$ and mean specific gravity of ten milk sample was $1.028 \mathrm{~g} / \mathrm{ml}$. Specific gravity and SNF percentage were low and not complied with Weerasekara et al. 2010.

Table 3: Variation of different quality parameters at farmer level

\begin{tabular}{llll}
\hline Character & Fat $\%$ & SNF\% & Specific gravity $\left(\mathrm{g} \mathrm{ml}^{-1}\right)$ \\
\hline Minimum & 3.8 & 8.34 & 1.026 \\
Maximum & 5.0 & 9.10 & 1.030 \\
Mean & 4.34 & 8.69 & 1.028 \\
\hline
\end{tabular}


According to the Table 4, collector level, fat percentage of milk samples varied within $3.7 \%$ to $5.2 \%$ range and mean fat percentage of milk samples was $4.34 \%$. This has not varied much between producer and collector level. The SNF percentage of ten milk samples varied within $8.05 \%$ to $9.1 \%$ range while mean SNF percentage was $8.45 \%$. The SNF\% at collector level was decreased when compared to farmer level. Also, specific gravity varied within 1.025 to $1.029 \mathrm{~g} \mathrm{ml}^{-}$ ${ }^{1}$ range and mean specific gravity of ten milk samples was $1.027 \mathrm{~g} \mathrm{ml}^{-1}$ which is comparable to producer level. The mean values of specific gravity, SNF, and fat percentage were not comparable to the standard (Weerasekara et al. 2010).

Table 4: Variation of different quality parameters at collector level

\begin{tabular}{llll}
\hline Character & Fat\% & SNF\% & Specific gravity $\left(\mathrm{g} \mathrm{ml}^{-1}\right)$ \\
\hline Minimum & 3.7 & 8.05 & 1.025 \\
Maximum & 5.2 & 8.94 & 1.029 \\
Mean & 4.34 & 8.45 & 1.027 \\
\hline
\end{tabular}

Table 5: pH variation of curd sample at processor level

\begin{tabular}{lllllllllll}
\hline $\begin{array}{l}\text { Sample } \\
\text { number }\end{array}$ & 01 & 02 & 03 & 04 & 05 & 06 & 07 & 08 & 09 & 10 \\
\hline $\mathrm{pH}$ & 4.84 & 4.79 & 4.72 & 4.71 & 4.73 & 4.72 & 4.82 & 4.75 & 4.7 & 4.8 \\
\hline Max. 4.84 & \multicolumn{1}{c}{ Min.4.7 } & & & & \\
\hline
\end{tabular}

The $\mathrm{pH}$ value variation of different curd samples at processor level is shown in Table 5. Further, processor level $\mathrm{pH}$ of ten curd samples varied within 4.7 to 4.84 range and mean $\mathrm{pH}$ of curd samples was 4.76. The $\mathrm{pH}$ values reported were not in conformity to the standards (Weerasekara et al. 2010).

\section{Conclusions}

Value chain management of dairy and dairy products is important because it describes how the activities are organized from farmer to consumer. The actors of Monaralgala district's dairy value chain consisted of input suppliers, farmers, collectors, processors, wholesalers, retailer and consumers. There are main four types of dairy value chains in the Wellawaya DS division. 
Out of the four main value chains, majority of the actors was linked to Chain A and it was the longest compared to other chains. Value Chain D was the shortest and the number of actors connected to this chain was also low. Profit share of each value chain actor was higher in the shortest value chain (Chain D) compared to other three. Farmers earned the highest profit in the shortest chain (Chain D). Length of the value chain or numbers of value chain actors are mainly affected to the variation of profit of each actor. Yoghurt and curd are the main value added dairy products found in the study area.

Farmers' average cost of production per liter of milk was $32 \mathrm{LKR}$ while farm gate price was 80 LKR. Also, price of the yoghurt was highly varied than price of the curd along the value chain from dairy farmer to consumer. Curd price at consumer level was increased by $36 \%$ and yoghurt price was increased by $77 \%$ compare to farm gate price. Market margin was 36\%. Farmer's share of the market margin was 64\%. Share of collector, processor, and retailer was 4\%, 20\%, and 4\% respectively. Farmers received fair profit through dairy value chain. It can be further concluded that prices of dairy product increased while slightly decreasing the quality. Product quality need to be improved throughout the value chain ultimately enabling to produce quality and safe products for consumers. Rising awareness of all the actors in the value chain about product quality requirements and importance and training them on quality control should gain priority attention of policy makers.

Conflicts of Interest: The authors declare that there are no conflicts of interest regarding the publication of this paper.

\section{References}

Department of Census and Statistics (2016) Household income and expenditure survey, Ministry of National Policies and Economic Affairs, Sri Lanka. Retrieved from http://www.statistics.gov.lk/HIES/HIES 2016/HIES2016_FinalReport.pdf

Department of Animal Production and Health (2019) Livestock statistical bulletin, Peradeniya. Sri Lanka. Retrieved from: http://www.daph.gov.lk/web/images/c ontent_image/news_bulletins/livestock_ statistical/livestock_statistical_bulletin_ volume_4_issue_1.pdf

Department of Animal Production and Health (2016) Annual report, 
Peradeniya, Sri Lanka. Retrieved from: http://www.daph.gov.lk/web/images/c ontent_image/publications/annual_repo rts/AnnualReport2015.pdf

Department of Animal Production and Health (2011) Annual report, Peradeniya, Sri Lanka. Retrieved from: http://www.daph.gov.lk/web/images/c ontent_image/publications/annual_repo rts/AnnualReport2011.pdf

Food and Agriculture Organization (2009) Smallholder dairy development: Lessons learned in Asia, Food and Agriculture Organization of the United Nations, regional office for Asia and the Pacific, Bangkok, January 2009. Retrieved from: http://www.fao.org/3/i0588e/I0588E0 0

Giangiacomo L, Scandurra R, Christova P, Karshikoff A, Knapp S, Ladenstein R (2000) Thermal unfolding and conformational stability of the recombinant domain II of glutamate dehydrogenase from the hyperthermophile Thermotoga maritime, Protein engineering, 13(7), pp.501-507.
Kaplinsky R, Morris M (2001) A Handbook for Value Chain Research, prepared for the IDRC. Institute of Development Studies: University of Sussex.

Porter M (1985) Competitive Advantage: Creating and Sustaining Superior Performance. New York.: Simon and Schuster. ISBN 9781416595847. Retrieved 9 September 2013.

Vernooij A, Houwers W, Zijlstra, J (2015) Emerging business opportunities in the dairy sector of Sri Lanka, Livestock Research Report, Wageningen UR (University \& Research centre).

Walzeem R L, Dillard C J, German J B (2002) Whey components: millennia of evolution create functionalities for mammalian nutrition: what we know and what we may be overlooking, Critical reviews in food science and nutrition, 42(4), pp.353-375.

Weerasekara W M S I M, Karunarathne G M C R, Pathapasinghe G A (2010) Assesment of quality parameters in curd and yoghurt of small scale processors in North Central Province, Wayamba journal of animal science. 